\title{
Heterogeneous FDI in Transition Economies - Advancing a novel approach to assess the developmental effects of backward linkages
}

\author{
Axèle Giroud \\ Axele.giroud@mbs.ac.uk \\ Björn Jindra, and Philipp Marek
}

This is a pre-print (non-publisher's document). Please cite the published article:

Giroud, Axèle, Björn Jindra, and Philipp Marek (2012), "Heterogeneous fdi in transition economies:A novel approach to assess the developmental impact of backward linkages," World Development, 40 (11). (DOI: 10.1016/j.worlddev.2012.03.018).

Summary. - Traditional models of technology transfer via FDI rely upon technology gap and absorptive capacity arguments to explain host economies' potential to benefit from technological spillovers. This paper emphasizes foreign affiliates' technological heterogeneity. We apply a novel approach differentiating extent and intensity of backward linkages between foreign affiliates and local suppliers, using survey data on 809 foreign affiliates in five transition economies. Our evidence shows that foreign affiliates' technological capability, embeddedness and autonomy are positively related to spillover potential. In contrast to what is widely assumed, we find a non-linear relationship between extent of local sourcing and knowledge transfer to domestic suppliers.

Key words - FDI, multinational enterprises, backward linkages, spillovers, transition economies, Central and Eastern Europe 
Note: This research has been partially financed by the EU Commission, in Framework Programme 6, Priority 7 on 'Citizens and Governance in a Knowledge-Based Society', contract number CIT5-028519. The authors are solely responsible for the contents, which might not represent the opinion of the Community. The Community is not responsible for any use that might be made of data appearing in this publication. 


\section{INTRODUCTION}

The relation between internationalization of firms, technology transfer and host-country effects has long been a concern in economic research. With the integration of post-communist countries into the global economy after 1990, there has been a strong research interest in the role of foreign direct investment (FDI) and multinational enterprises (MNEs) in economic restructuring and technological catch-up. Unlike many developing countries, East European transition countries started out with an existing industrial structure and relatively educated workforce. Their economies were also close to developed European markets, and most embarked on comprehensive privatization processes at a time when FDI was starting to peak worldwide.

The bulk of existing research on FDI effects in transition economies is based on the standard production function approach. It measures the effects of FDI presence in terms of employment or valueadded on domestic firms' total factor or labor productivity. Studies that assess vertical effects use intersectoral linkage coefficients in order to weigh foreign presence in related sectors. Linkage coefficients are derived from input-output tables at sector level and assumed to apply homogeneously to all firms within the given sector. Significant effects of foreign presence on domestic productivity are interpreted as indirect evidence for non-pecuniary technology or knowledge spillover effects.

This approach goes back, conceptually, to Findlay (1978), who suggested a model endogenizing the rate of technical change in a backward region as a function of its exposure to foreign capital. He refers to Hymer (1960), who suggested that FDI constitutes a transfer package combining capital, management and new technology. Applying the concept of relative backwardness in economic development (Veblen, 1915; Gerschenkron, 1962), Findlay holds that the potential for technological diffusion via FDI is positively linked to the relative technology gap between the home and host economies.

Teece (1976), however, fundamentally challenged the position that technology can be made available to all at zero social cost. He argued that technology transfer requires the commitment of real resources, 
and that transfer costs decline with each application of innovation. Thus, Wang and Blomström (1992) recognize two types of costs associated with technology diffusion - costs to the MNE transferring technology to its affiliate, and learning costs of domestic firms. The latter aspect has also been associated with the concept of 'absorptive capacity' (Cohen \& Levinthal, 1990), which implies that domestic firms need to invest in their own R\&D to be able to identify, assimilate and exploit knowledge from foreign firms.

The existing empirical evidence on FDI-induced knowledge spillovers is mixed for transition economies (see Rugraff, 2008; Meyer \& Sinani, 2009 for an overview). It indicates that knowledge spillovers are more likely to occur through vertical linkages than between competitors within the same sector (Jindra, 2005; Damijan, Rojec, Majcen \& Knell, 2008). In particular, backward linkages from foreign subsidiaries to domestic suppliers seem to facilitate technology spillovers (Javorcik-Smarzynska, 2004; Halpern \& Muraközy, 2007; Damijan et al., 2008). The existing evidence highlights domestic firms' absorptive capacity as an enabling factor for positive externalities through FDI backward linkages (Crespo \& Fontoura, 2007; Damijan et al., 2008).

However, the existing research on FDI effects via backward linkages in transition economies based on the production function approach is subject to three possible criticisms:

First, the standard production function approach estimates FDI spillover via backward linkages by using industry-level input-output coefficients, used as proxy for trade linkages between sectors. This implies, on the one hand, that within any given sector domestic and foreign firms are homogeneous with regard to local sourcing. On the other hand, it implies a linear relationship between the extent of local sourcing and knowledge spillovers, which has been challenged for transition and developing countries (Pavlínek \& Janak, 2007; Dunning \& Lundan, 2008; Saliola \& Zanfei, 2009; Narula \& Dunning, 2010; Rugraff, 2010; Gentile-Lüdecke \& Giroud, 2012).

Second, the standard production function approach assumes that foreign firms are technologically homogeneous, i.e. every foreign firm provides the same knowledge opportunities or spillover potential for 
domestic firms. This is in contrast to the most recent models (Chung, 2001; Marin \& Bell, 2006; Castellani \& Zanfei, 2006; Driffield \& Love, 2007; Marin \& Sasidharan, 2010), which argue that factors such as the technological strategy of the foreign parent firm, the extent of knowledge-enhancing activities by the foreign affiliate, and its propensity to establish technological co-operation with other domestic firms affect the extent of knowledge spillovers to domestic firms.

Finally, Zanfei (2012) maintains that literature using the standard production function approach has largely remained stuck to the externality framework, which by definition entails the idea of 'not-paid-for' advantages accruing to local firms from the activities of foreign firms. However, knowledge transfer between foreign and local firms is not costless (Teece, 1976). For this reason, Zanfei focuses on the broader category of 'effects' rather than 'externalities' from foreign presence to fully capture the links between FDI and development.

This paper does not apply the standard production approach and continues earlier work differentiating between extent and intensity of backward linkages (Giroud \& Scott-Kennel, 2009; Jindra, Giroud, \& Scott-Kennel, 2009; Jordaan, 2011). In principle, extent relates to the level of use of local suppliers by foreign firms. Following a long tradition of studies dating back to Hirschman (1958), Lall (1980) and Rodriguez-Clare (1996) under specific assumptions, this can generate pecuniary externalities for foreign and local firms. The intensity of backward linkages can be defined as direct and intentional knowledge flows between the foreign affiliate and local suppliers, which are not costless. This constitutes a novel approach to assessing the developmental 'effects' of FDI via backward linkages, complementary to the widely used production function approach.

This paper has two main objectives: First, it tests whether the relationship between extent and intensity of backward linkages follows a linear or non-linear pattern. Second, it analyzes how foreign affiliates' technological heterogeneity impacts on the intensity of backward linkages. In order to investigate these two research questions, we develop a model for the intensity of backward linkages which we apply to foreign affiliate-level survey data from five Central and East Europe transition countries at different levels of economic development. 
This paper is structured as in the follows: Section 2 reviews the literature on the nature and determinants of backward linkages, to set the key research hypotheses into an appropriate context. Section 3 introduces the data and presents selected descriptive statistics. Section 4 describes the estimation approach and variables used, and Section 5 provides a discussion of the results. Concluding remarks are developed in Section 6, including limitations and possible future research avenues.

\section{LITERATURE REVIEW AND RESEARCH QUESTIONS}

\subsection{Relationship between extent and intensity of backward linkages}

Authors have long distinguished spillovers from linkages by emphasizing the nature of the direct relationship between an MNE and its local suppliers, but only recently has that attention turned to the need to distinguish between the pecuniary effects of linkages from the development potential arising from knowledge transfer.

Hirschman (1958) suggests that particular investments create external economies in sectors that supply or buy from them, so that new investments are undertaken in order to exploit them. Foreign investment is assigned a vital role, "to enable and to embolden a country to set out on the path of unbalanced growth ... [and] to take the first "unbalancing" steps in growth sequences". Lall (1980) holds that, in Hirschman's analysis, linkages could be said to exist in developing countries when a rise in demand (or supply) of one product raises (or lowers) its price to an extent that latent entrepreneurship is stimulated and complementary investments undertaken. Rodriguez-Clare (1996) uses Hirschman-type linkage externalities, combined with an assumed love of variety, for inputs in final production to formalize linkage effects. The essence of this type of linkage is the pecuniary externality created by price changes in inputs used in production, which affect the profit rather than production function of domestic firms (Zanfei, 2012).

An MNE exercises its voice (in Hirshman's approach) when it works with suppliers to reach desired levels of quality; in other terms, the catalyst impact described by Rodriguez-Clare (1996) may result from direct knowledge transfer when an MNE provides technological assistance to suppliers to increase supply 
quality and efficiency. Such transfers occur through various actions: (a) information on markets, regulations, pricing, exporting, location of production; (b) technical assistance on product design, quality control, factory outlet, labor, inventory management; (c) financial, management and procurement assistance (Lall, 1980; Jordaan, 2011; Gentile-Lüdecke \& Giroud, 2012). In this case, knowledge transfer from a foreign affiliate affects directly the technology used by a local supplier, i.e. it shifts its production function.

This suggests that it is important to distinguish between the extent and intensity of backward linkages (Giroud \& Scott-Kennel, 2009; Jindra et al., 2009; Jordaan, 2011), i.e. to differentiate between benefits derived from an increase in demand from those derived from technological, innovation, organizational or managerial support received by suppliers from MNEs (Crespo \& Fontoura, 2007:412). The intensity of linkages reflects the supply-side effects described by Lin \& Saggi (2007), i.e. the technological relationships between the foreign affiliate and suppliers. Intensity matters because technology is not available at zero cost, and MNEs are therefore likely to be selective in where and when they engage in the accrued costs of transferring knowledge to local suppliers (Teece, 1976; Zanfei, 2012). The absence of a technological relationship between the foreign affiliate and suppliers limits not only direct knowledge transfer, but also the extent of non-pecuniary knowledge (or technology) externalities to other firms of the indigenous industrial sector (Rugraff, 2010).

Now the question emerges what relationship exists between the extent and intensity of backward linkages. The standard production function approach assumes a positive linear relationship between the share of local inputs bought by foreign affiliates in one industry (extent) and the extent of non-pecuniary knowledge (or technology) externalities via backward linkages to domestic suppliers in linked industries (see Damijan et al., 2003, or Javorcik-Smarzynska \& Spatareanu, 2011).

However, evidence from the literature of knowledge transfer via backward linkages questions this. For example, Saliola and Zanfei (2009) find in the case of Thailand that the more MNEs buy inputs locally, the higher the likelihood of value-chain relationships being characterized by a very limited transfer of knowledge. Why should this be so? Local firms may be locked-in in low added functions, or the local 
industry may be reliant on standardized parts and processes (Gentile-Lüdecke \& Giroud, 2012). For some industries, such as the automotive industry, the new production and organization paradigm has led to reconfiguration of the MNE-developing country relationship, with a core group of first-tier 'megasuppliers' (Rugraff, 2010). In this case, very few suppliers benefit from a close relationship with the foreign affiliate, with local suppliers mostly in lower-tier positions where the complexity of the components supplied is limited (Pavlínek \& Janak, 2007). This reflects both the strategy of the modern rationalized and efficiency-seeking MNE, and inherent limitations of suppliers in countries at lower levels of industrial development (Dunning \& Lundan, 2008; Saliola \& Zanfei, 2009; Narula \& Dunning, 2010).

Thus, it is possible that high local purchasing may signal that a foreign affiliate in transitional and developing countries is more concerned with cost-saving than with quality and knowledge content. It might also be that when a foreign affiliate combines imported and locally-sourced inputs in production, this could trigger knowledge transfer to local suppliers in order to comply with international and complex production standards. This suggests a non-linear relationship between the extent and intensity of backward linkages. To the best of our knowledge, this relationship has not yet been tested. Therefore, we hypothesize:

H1. The relationship between the extent and intensity of foreign affiliates' backward linkages with suppliers in the host economy follows a non-linear distribution.

\subsection{Heterogeneity of subsidiaries and backward linkages intensity}

Narula \& Dunning (2010:275) argue in favor of moving away from FDI towards MNEs when analyzing host-country impact, because individual subsidiaries possess unique capabilities, and therefore "the subsidiary itself may provide unique, subsidiary-specific spillovers to the domestic economy and for this reason its strategic decisions in terms of sourcing and linkages may differ from that of a sister subsidiary in another host location, not just from that of its headquarters". Castellani \& Zanfei (2006) suggest that heterogeneity across and within MNEs should be taken into consideration. Heterogeneity across MNEs implies that foreign firms differ with respect to country of origin, level of internationalization and entry 
mode. The main point of within-MNE heterogeneity is that not every MNE affiliate is equally involved in the creation, adoption and, importantly, diffusion of innovation in the host environment. In fact, a number of FDI spillover studies challenge the assumption that foreign affiliates are technologically homogeneous (Castellani \& Zanfei, 2006; Driffield \& Love, 2007; Marin \& Sasidharan, 2010). To better understand the effect of within-MNE heterogeneity on backward linkage intensity in transition and developing economies, the international management literature is useful, as it explains why an affiliate creates knowledge and capabilities in resource interdependencies in the MNE and host-country contexts (Andersson \& Forsgren, 2000; Yamin \& Otto, 2004).

(a) Heterogeneous local technological activities of subsidiaries

Marin \& Bell (2006) argue that non-pecuniary knowledge (or technology) spillovers arise only if foreign affiliates are engaged in local knowledge-creating activities such as R\&D or innovation. Marin \& Sasidharan (2010) further suggest that foreign affiliates implementing a competence-augmenting vs. competence-exploiting technological strategy are more likely to generate positive non-pecuniary knowledge (or technology) spillovers. We take up this argument and assume a direct link between foreign affiliates' technological activities and knowledge transfer to local suppliers. Empirical evidence on the nature of foreign affiliates' technological activities in transition economies has only recently emerged: Manea \& Pearce (2006) found that, in the 1990s, foreign affiliates relied largely on technology already in existence in the MNE group, as opposed to own-technology developed through R\&D. Günther, Jindra \& Stephan (2009), using more recent data, show that tapping into localized knowledge, skills and technology seems to be of secondary importance; yet the majority of foreign affiliates are actively engaged in $R \& D$ and innovation, although fewer foreign firms build technological linkages with local scientific institutions. Finally, Jindra et al. (2009) identified that foreign affiliates that consider themselves an important source of technological knowledge for own $\mathrm{R} \& \mathrm{D}$ and innovation have more intense backward linkages to domestic suppliers. These recent findings indicate a positive relationship between foreign affiliates' technological activity and backward linkages intensity; thus, we hypothesize: 
H2. The level of foreign affiliates' technological activities is positively associated with the intensity of backward linkages with suppliers in the host economy.

(b) Affiliate-parent considerations

Local autonomy over production and technology

Transaction costs theory suggests that the decision to internationalize firm-specific advantages, such as proprietary technology, through FDI can be explained by the public-good nature of knowledge, as armslength contractual relationships may be plagued by opportunistic behavior (Williamson, 1985). From this perspective, the foreign affiliate is in a position to control firm-specific knowledge and will either limit undesired technology diffusion to suppliers, or favor long-term relationships with them. In this context, the foreign parent has full control over the affiliate.

However, foreign affiliates with a higher level of own initiative have the ability to change their valueadding scope and also be more flexible in their relationships with suppliers (Birkinshaw, Hood \& Jonsson, 1998). In fact, existing empirical studies suggest that the greater the autonomy of foreign affiliates, the more likely they are to identify local suppliers and create close relationships (UNCTAD, 2001; Eberhardt, McLaren, Millington \& Wilkinson, 2004). This would hint at a positive link between foreign affiliates' autonomy and the extent of backward linkages. It has also been argued that autonomy is an indicator of the affiliate's strategic importance and leads to higher local sourcing (Liu, 2010). Specifically, autonomy over production and technology enables affiliates to generate independent competencies and use a wider range of local inputs creatively (Cantwell \& Iguchi, 2005). This in turn, would suggest that autonomy, in particular over technology-related business functions, is positively associated with the intensity of backward linkages. Thus, we hypothesize:

H3a. The greater foreign affiliates' autonomy over technological business functions, the higher the intensity of backward linkages with suppliers in the host economy. 
In addition to the current level of foreign affiliates' autonomy over technology-related business functions, we also need to consider any changes to the scope of functions undertaken by a foreign affiliate over time. Firstly, as an affiliate becomes more capable of developing its own competencies, it becomes less dependent on resources from its parent firm (Birkinshaw et al., 1998). Secondly, transfer of business functions to an affiliate may occur if the MNE has identified benefits from knowledge gained in the host environment (Yamin \& Otto, 2004). As a result of having control over new business functions, the affiliate can better respond to demands in the local environment, and in particular the intensity of local business relationships. This is in line with the argument that 'competences' of a foreign affiliate engender non-pecuniary spillovers to domestic firms (Crespo \& Fontoura, 2007) and generate 'higher levels' of linkages in host developing economies (Hansen, Pedersen and Petersen, 2009). Thus, we hypothesize:

H3b. The greater the extent of competence transfer with regard to new business functions to the foreign affiliate, the higher the intensity of backward linkages with suppliers in the host economy.

(c) Affiliate's internal and external technological embeddedness

According to Cantwell (1995), the traditional organizational model of the MNE, based on the vertical unidirectional transfer of knowledge from the parent towards foreign units, is being gradually replaced by a model wherein foreign units are increasingly tied into MNE internal networks and tend to develop external networks with other firms and institutions, in order to increase the potential for use and generation of knowledge. According to Zanfei (2000), the emergence of this so-called 'double-network' structure is favored by the need to transfer context-specific knowledge via MNEs' internal networks for use in different places, as well as the importance of gaining access to abilities to utilize this knowledge creatively via external networks. It has been suggested that internal and external networks may co-exist, reflecting a dynamic interdependence and complementarity (Castellani \& Zanfei, 2006). Research stressing dynamic efficiency concludes that an expansion of firms' international internal networking will increase their exploration potential to search and absorb external knowledge (Cantwell, 1995; Figueiredo, 2011). 
Foreign affiliates' technological capabilities originate not only from their own competences, but resources acquired inside the MNE network (Gupta \& Govindarajan, 2000) and externally in the host economies (Almeida \& Phene, 2004; Yamin \& Otto, 2004; Belderbos, Carree \& Lokshin, 2006; Figueiredo, 2011). The creation of internal networks of affiliates may generate new technological opportunities and induce affiliates to set up external networks for asset-seeking (Castellani \& Zanfei, 2006). This suggests not only a link between a foreign affiliate's embeddedness in internal networks and its technological capabilities, but also the embeddedness of its technological activities within the MNE and the potential intensity of backward linkages to local suppliers in the host economy. In fact, Jindra et al. (2009) found evidence to support this. Therefore, we hypothesize:

H4a. Foreign affiliates' internal technological embeddedness is positively associated with the intensity of backward linkages with suppliers in the host economy.

The technological competences of foreign affiliates are closely related to network embeddedness and also to external technological co-operation (Belderbos et al., 2006). A foreign affiliate's external network links can improve its strategic position within the MNE (Forsgren, Holm \& Johanson, 2006). For example, the ability of a foreign affiliate to influence product development within the MNE depends on whether it has valuable links to its customers and suppliers with regard to new product development (Andersson \& Forsgren, 2000). Given that technological activities such as R\&D co-operation, joint product development, co-design and standards setting facilitate explicit and tacit knowledge flows between the foreign affiliate and local suppliers (Castellani \& Zanfei, 2006), we also hypothesize:

H4b. Foreign affiliates' external technological embeddedness is positively associated with the intensity of backward linkages with suppliers in the host economy.

\section{DATA AND DESCRIPTIVE ANALYSIS}

\subsection{Description of population and sample}


To verify our research hypotheses, we use the 2007 survey of the IWH$^{1}$ FDI Micro Database. The total underlying population consists of foreign-owned manufacturing firms located in Croatia, Slovenia, Poland, Romania and East Germany in 2006. The selection of these regions in economic transition tries to balance country size, geographic location and differing levels of economic development.

A number of reasons prompted us to include East Germany: Firstly, studies on transition economies often exclude East Germany because of theoretical and empirical difficulties derived from the fact that it became subsumed into a larger and more mature economy. In fact, it followed a distinct transition pattern, characterized by rapid institutional change, and considerable public transfer payments, in contrast to other transition economies - as such, it represents a useful comparative case. Secondly, there has been an absence of harmonized firm-level data on linkages of foreign firms in transition economies. This paper exploits standardized affiliate-level data on production as well as technological linkages covering five key transition economies, including East Germany. Thus, the sample reflects heterogeneous patterns of economic transition and stages of economic development in Central and Eastern Europe.

A 'foreign-owned firm' is defined as a legally independent enterprise with a foreign equity participation of at least $10 \%$ and/or an ultimate owner located abroad. Given their importance for the transition process, the East Germany population also includes affiliate of multinationals based in West Germany (see Günther et al., 2011). The populations of foreign-owned firms for Poland, Romania and East Germany were drawn from the Amadeus database. For completeness, the Polish and East German populations were supplemented with data from the respective foreign investment agencies (Invest in Germany - IIG; Invest in Poland - PAIZ), and for East Germany with information from the European Investment Monitor (2006 edition) and the EU's industrial R\&D investment scoreboard (2005 edition). The Croatian population was compiled using information provided by the Institute for Business Intelligence (Zagreb/Croatia), while the Slovenian population was drawn from statistics provided by the Bank of Slovenia. Although care was taken to develop as precise a company list as possible, we acknowledge that the 2007 IWH Micro database is not drawn from a single source with a unified selection criterion for all countries. This is a methodological drawback. Nonetheless, the 2007 survey is the most complete firm-level database on foreign affiliates in transition economies, and is unique in that it contains detailed information on backward linkages between foreign subsidiaries and local firms. 
The total surveyed population across the five countries consists of 6,833 firms with about 1.1 million employees (220 foreign affiliates in Croatia, 365 in Slovenia, 1,511 in Poland, 3,325 in Romania, and 2,222 for East Germany, of which 322 were West German firms). The large share of Romanian firms is related to differences in the completeness and quality of country datasets drawn from the Amadeus database. In principle, no restriction in terms of firm size was introduced, yet our Croatian and Romanian participants decided to include only foreign-owned firms with a minimum of 10 employees. The population is restricted to manufacturing industries (NACE Rev 1.1: 15 to 37). In terms of number of firms, the three largest sectors are manufacture of food products and beverages (NACE 15), wearing apparel and dressing (NACE 18), and fabricated metal (NACE 28). This sectoral composition is influenced by the Romanian population of foreign firms and there are differences in sector composition across countries.

Data was collected via a large-scale survey between January and June 2007. All firms in the population were approached by post or phone and invited to participate in the survey. Firms received the questionnaire by post, fax or electronically. In Romania, due to the large population size, a random sample was drawn; firms received the questionnaire by post, followed by face-to-face interviews. In East Germany, all firms from the population were contacted by phone and invited to take part in the survey, and data was collected both in written form and though phone interviews. The project deliberately allowed the country teams to choose the most appropriate survey method.

\section{*Insert Table A about here*}

The generated sample of foreign affiliates is one of the largest for transition countries to date. It consists of 809 foreign-owned affiliates, accounting for a total of 214,000 employees. The sample accounts for $11.84 \%$ of the total population in terms of number of firms, and $19.05 \%$ in terms of employment. It is representative of the full population across sectors, with only small variations (less than $3 \%$ in terms of the number of firms and less than $5 \%$ in terms of employment).

Response rates varied across countries (see Table A). In terms of number of firms, it ranged from $6.62 \%$ in Poland to $65.45 \%$ in Croatia; in terms of employment, from $11.12 \%$ of the sample of West German multinational-owned firms in East Germany to $65.97 \%$ in Croatia. Importantly, if we look at the 
share of each country in the resulting sample, the distribution follows the underlying population (see Table A). The differences in response rates across countries reflect national diversity in attitudes towards firmlevel surveys rather than systematic error. In terms of distribution of firms across size classes, the sample is under-represented for micro (1-9 employees) and small enterprises (10-49). Therefore, we acknowledge a need for caution when interpreting country- or size-specific effects in our results.

\subsection{Descriptive analysis}

Table 1 shows the supply structure of foreign affiliates in the sample. On average, about $48 \%$ of inputs are bought from domestic suppliers (domestic suppliers consist of foreign- and locally-owned suppliers located in the host transition economy), about 28\% sourced from within the MNE network, and about 24\% imported from other suppliers located in other countries. Thus the extent of backward linkages (measured as the share of inputs bought from domestic suppliers) is substantial.

\section{*Insert Table 1 about here*}

We find that the extent of backward linkages varies across countries. It is highest for East Germany (57\%), followed by Poland (53\%), Slovenia (44\%), Croatia (43\%) and Romania (38\%). The mean extent of backward linkages in comparison to the respective remainder of the full sample is significantly higher in the East German and Polish sub-samples. It is significantly lower for the Romanian, Croatian and Slovenian sub-samples. We measured the intensity of backward linkages by asking the foreign affiliate to assess its perceived 'importance as source of technological knowledge for R\&D or innovation for domestic suppliers' at the time of survey. Foreign affiliates could provide answers on a scale ranging from 1 (not important) to 5 (extremely important). Again, we find that the mean of backward linkage intensities varies across countries (see Table 2). It is highest in the case of Poland (2.53), followed by Romania (2.45), Slovenia (2.25), Croatia (2.20) and East Germany (1.84). The mean intensity of backward linkages in comparison to the respective remainder of the full sample is significantly higher in Poland and Romania and significantly lower for East Germany. This first descriptive evidence therefore indicates that the distribution of backward linkage intensities across countries does not follow the distribution of the extent of backward linkages. 


\section{*Insert Table 2 about here*}

We also find differences in the extent and intensity of backward linkages across industries ${ }^{2}$, differentiated by their technological intensities (see Table 3). The mean extent of backward linkages is significantly higher for foreign affiliates in medium-low tech industries and significantly lower for foreign affiliates in low-tech industries. The mean of backward linkage intensities falls with the technological intensity of the industry. The intensity of backward linkages for foreign affiliates in high-tech industries is significantly lower than that of other firms in the sample. These descriptive results indicate that foreign investors in high-tech industries do not, per se, generate a higher potential for technological spillovers.

*Insert Table 3 about here*

\section{ESTIMATION APPROACH}

This paper does not rely on productivity measures, but instead continues existing empirical work (see for example Jindra et al., 2009; Jordaan, 2011) differentiating between the extent and intensity of FDI backward linkages using survey evidence. This approach complements the traditional production function approach. The main advantage is that we are able to exploit affiliate-level detailed information on trade and technological linkages between foreign affiliates and domestic firms. This way, we can not only identify the actual share of local supplies (extent of backward linkages), but also gather information on the importance of the foreign affiliate as a source of technological knowledge for $R \& D$ or innovation for domestic suppliers (intensity of backward linkages). However, it should be noted that, as this approach is applied to survey data from foreign affiliates, it is unable to infer anything about the economic effect of knowledge transfer to domestic firms.

\section{*Insert Table 4 about here*}

We measure the extent of backward linkages $\left(B L_{i}\right)$ by the share of supplies from domestic firms in total supplies (see Table 4). Specification (la) estimates the extent of backward linkages (BL) of affiliate $i$ as a linear function of the constant $\alpha$ and the coefficients of the following explanatory variables: level of technological activity (INNO) of affiliate $i$; autonomy over operational and production management (AUTprod) of affiliate $i$; autonomy over R\&D (AUTrd) of affiliate $i$; degree of responsibility transfer over 
business functions (AUTtransfer) to affiliate $i$; external technological embeddedness (TEext) of affiliate $i$; and internal technological embeddedness (TEint) of affiliate $i$ (see Table 4 for a detailed description of variables). The main explanatory variables are complemented with a set of firm-, industry- and countryspecific control variables: share of local sales in total sales $(L S)$ of affiliate $i$, time since entry $(A G E)$ of the affiliate $i$; mode of entry (EM) of subsidiary $i$, a dummy for the technological intensity of the industry (INDdum) in which subsidiary $i$ operates; as well as a dummy for the host country (Cdum) in which the affiliate $i$ is located. Given that the share of domestic supplies as dependent variable can be considered a continuous variable between 0 and 100, we apply, as a first step, an Ordinary Least Squares (OLS) estimator to specification $(1 a)$, which can be described as follows:

(1a)

$$
\begin{aligned}
& \boldsymbol{B L}_{i}=\alpha+\beta_{1} \text { INNO }_{i}+\beta_{2} \text { AUTprod }_{i}+\beta_{3} \text { AUTrd }_{i}+\beta_{4} \text { AUTtransfer }_{i}+\beta_{5} \text { TEext }_{i}+\beta_{6} \text { TEint }_{i}+ \\
& \beta_{7} \text { LS }_{i}+\beta_{8} A G E_{i}+\beta_{9} \text { EM }_{i}+\beta_{10} \text { SIZE }_{i}+\beta_{11} \text { INDdum }_{i}+\beta_{12} \text { Cdum }_{i}+\varepsilon_{i}
\end{aligned}
$$

Given that the share of domestic supplies in total supplies is limited by a lower (0) and upper boundary (100), the distribution shows proportionally higher frequencies at the lower and upper boundaries. This could bias the OLS estimates results. Therefore, in a second step we use a Tobit estimator in order to check the robustness of the OLS results. The corresponding specification (lb) of backward linkages can be described as follows:

(1b) $\quad \boldsymbol{B L}_{i}^{*}=\alpha+\beta_{1} I_{N N O_{i}}+\beta_{2}$ AUTprod $_{i}+\beta_{3}$ AUTrd $_{i}+\beta_{4}$ AUTtransfer $_{i}+\beta_{5}$ TEext $_{i}+\beta_{6}$ TEint $_{i}$$$
+\beta_{7} L S_{i}+\beta_{8} A G E_{i}+\beta_{9} E M_{i}+\beta_{10} S I Z E_{i}+\beta_{11} I_{N D d u m_{i}}+\beta_{12} C d u m_{i}+\varepsilon_{i}
$$$$
B L_{i}=0 \text { if } B L_{i}^{*}<=0 \text {, }
$$$$
B \boldsymbol{L}_{i}=\boldsymbol{B} \boldsymbol{L}_{i}^{*} \text { if } 0<B L_{i}^{*}<100 \text {, }
$$$$
B L_{i}=100 \text { if } B L_{i}^{*}>=100 \text {. }
$$

We measure Backward linkage intensity $\left(B L I_{i}\right)$ by 'the importance of the foreign affiliate as a source of knowledge relevant for R\&D and innovation for domestic suppliers' (with a Likert-scale measure from 1 Not important to 5 - Extremely important). As this dependent is a ranked variable with five ordered outcomes, we apply an Ordered Probit estimation procedure with four threshold parameters, $\tau_{j}(j=1,2,3,4)$. 
Specifications $(2 a)$ and $(2 b)$ estimate the probability of the intensity of backward linkages $(B L I)$ of affiliate $i$ as a linear combination of the explanatory variables used in Specifications $(1 a)$ and $(1 b)$. In addition, we use two ways to test the assumption of non-linearity between extent and intensity of backward linkages. In specification $(2 a)$, we include a quadratic term of the extent of backward linkages $\left(B L^{2}\right)$ of affiliate $i$. This could indicate an inverted U-shaped rather than linear functional form.

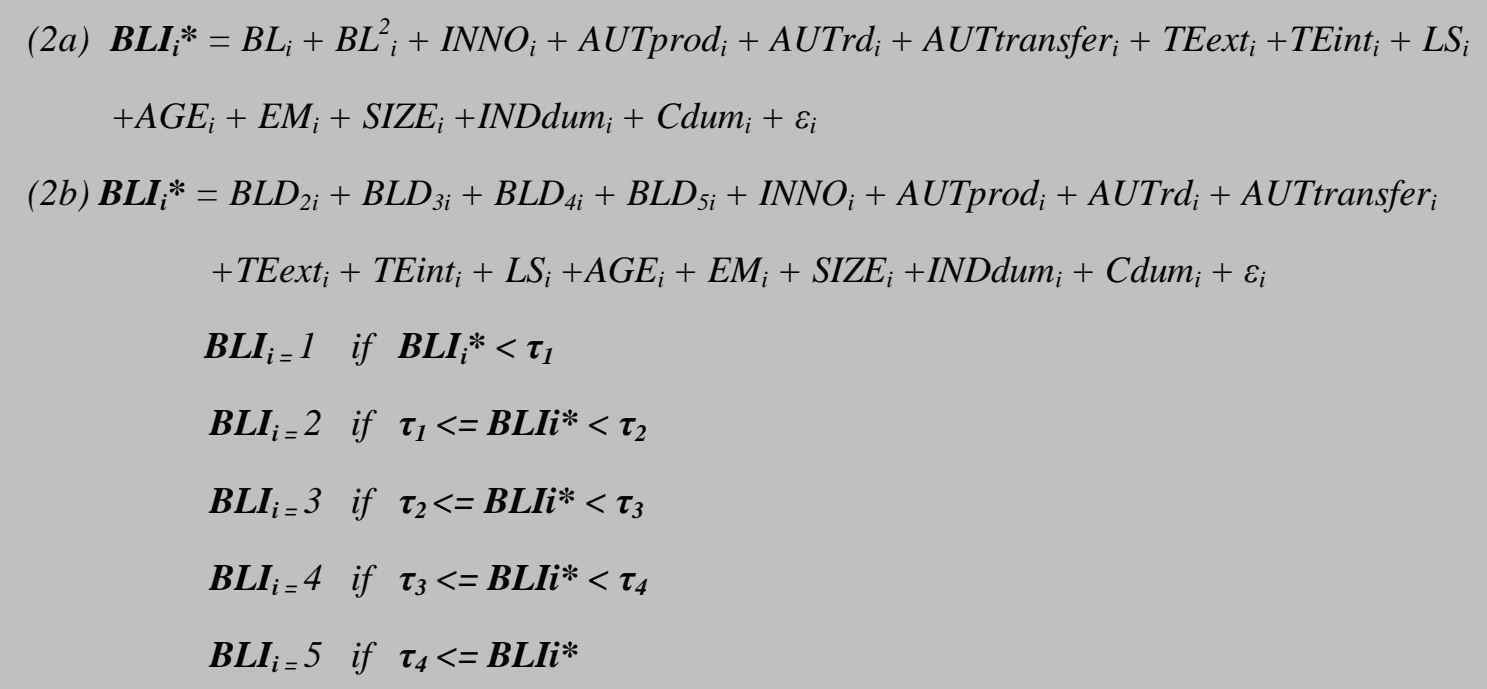

We acknowledge that the estimation results of Specification 2a could merely reflect 'decreasing returns' (i.e. a monotonically increasing square-root-like function), rather than an inverted U-shape. In this case, the inverted-U could be a result of functional form mis-specification, 'forcing' the quadratic function on non-linear data. Therefore, in Specification $2 \mathrm{~b}$, we estimate the function non-parametrically by including five interval dummies ${ }^{3}$ of extent of backward linkages ( $B L D k$ with $k=1,2,3,4,5$ ). Should the impact of the extent of backward linkages on intensity be linear, the coefficient estimates would increase linearly. We test this aspect by means of a Likelihood-Ratio Test, which compares the unrestricted model with a restricted model. The restriction is implied by setting the differences between the coefficients of subsequent interval dummies as equal. To check whether the extent of backward linkages has an impact on backward linkage intensity after passing a threshold level, we apply an additional restriction in specification $(2 b)$ with a corresponding LR Test. This is done by setting the coefficient of the $3^{\text {rd }}, 4^{\text {th }}$ and $5^{\text {th }}$ interval dummy equal to the coefficient estimate for the $2^{\text {nd }}$ interval dummy. This restriction implies that the impact of extent of backward linkages does not change after passing a share of $20 \%$. 
Because of the limited number of observations in our final sample, multicollinearity may lead to problematic estimates, when introducing up to seven key variables and several control variables in the regressions. For this reason, we introduce explanatory variables in several steps. When reporting Specification 2a, we first present a regression that includes only extent of backward linkages, the quadratic term, as well as industry and country dummies. In a second step, we present a regression that includes firm-specific effects, followed by a complete model including additional firm-specific variables. The complete model is also estimated non-parametrically under Specification $2 \mathrm{~b}$.

Some of the key explanatory variables included in Specifications $2 \mathrm{a}$ and $2 \mathrm{~b}$ may be determined simultaneously. For example, it could be argued that when foreign affiliates make a choice about extent of backward linkages, they might take into account the potential intensity of these linkages, i.e. how much supplier upgrading is required through knowledge transfer from the affiliate for the supplier to comply with price and quality standards. This may create an endogeneity problem and our estimation results may reflect correlations rather than causal effects. We acknowledge this limitation, but given the limited sample size, we are unable to conduct efficiently an instrumental variable procedure that would remove potential endogeneity problems.

We estimate all specifications on a final sample of 520 observations that supplied full information on both dependent and all independent variables. The difference compared to the full sample of 809 observations is explained by missing values for the required combination of variables. However, our final sample reflects the full sample in terms of country distribution. Results from both specifications can be compared, as we included the same observations in both estimations.

\section{ESTIMATION RESULTS AND DISCUSSION}

Using an OLS model, Specification 1a is overall significant and explains about $20 \%$ of total variance in the extent of backward linkages (see Table 5). Specification 1b was estimated using a Tobit estimator. With a log-pseudo likelihood value of -2116.7, the model is overall significant, as shown by the probability value of the F-Statistics. The corresponding McFadden's Pseudo $\mathrm{R}^{2}$ has a value of 0.027 (see Table 6). All models reported in Tables 7 and 8 are significant. Specification 2a on the intensity of backward linkages was estimated using an ordered Probit estimator. It shows a log-pseudo likelihood value of -636.7. The unrestricted Specification $2 b$ on the intensity of backward linkages was estimated 
using an ordered Probit estimator and included the interval dummies. It shows a log-pseudo likelihood of 635.4. The restricted specification of the ordered Probit estimation (2b) with linearly increasing coefficients of the dummy variables for the intensity of backward linkages shows a log-pseudo likelihood value of -645.9. Finally, the Specification $2 b$ with the threshold restriction for the interval dummies has a log-pseudo likelihood value of -636.3 (see Table 8).

*Insert Tables 5 to 8 about here*

\subsection{Extent and intensity of backward linkages}

The ordered Probit estimation on the intensity of backward linkages shows a significant positive coefficient for the extent of linkages and a significant negative effect of the corresponding quadratic term (see Table 7). The result remains robust in all reported regressions. Thus, Hypothesis 1 cannot be rejected at this stage. However, the estimation results of Specification 2a could reflect a monotonically increasing square-root-like function rather than an inverted U-shape, although the maximum of the estimated quadratic function is at $67.8 \%$. Therefore, in Specification $2 \mathrm{~b}$ we estimated the function nonparametrically (see Table 8). The estimation results for the interval dummies indicate that the effect of domestic supplies on backward linkage intensity is levelling off. It seems there are 'decreasing returns' with increasing shares of domestic supplies. Thus, we still cannot reject Hypothesis 1. Under Specification $2 \mathrm{~b}$, the linear impact of the extent of backward linkages can be tested by means of a LR-Test between the unrestricted and restricted models. The regression outputs show a LR-Test statistic of 20.87. Since the restricted model is exposed to three restrictions, the probability value for the test refers to three degrees of freedom and corresponds to 0.000 . Thus, the assumption of linearly increasing coefficients of the interval dummies can be rejected.

Next, we test whether the impact of the extent of backward linkages on the backward linkage intensity remains stable after reaching a threshold value of $20 \%$. The comparison between the unrestricted model and the threshold restriction leads to a LR-Test statistic of 1.865 and a corresponding probability value of 0.7982, with three degrees of freedom. This result provides additional evidence that the relation between 
the extent and intensity of backward linkages is not linear. The latter LR test suggests a plateau-shaped relation after the extent of backward linkages reaches a threshold of $20 \%$, rather than an inverted U-shape. In sum, we show robust results of a non-linear relationship between extent and intensity of backward linkages.

Our finding is in line with the result obtained by Saliola \& Zanfei (2009) in their study on backward linkages in Thailand. They argue that when inputs are sourced in developing countries, a high share of local purchases may signal that MNEs are more concerned with cost-saving than with quality and knowledge content. However, our results indicate a non-linear relationship between extent and intensity of backward linkages, independently from the level of the host country's industrial development (illustrated by the fact that we control for fixed country effects in a multi-country sample of heterogeneous transition economies).

Therefore, our result calls for an alternative explanation. One option could be that knowledge flows are more intense when local inputs are combined with other imported inputs in the production process of the foreign affiliate. This could require product and process upgrading for domestic suppliers, in order to converge to international product standards and enhance overall efficiency and productivity, allowing for low prices while achieving high product quality. This has, for example, been described in case of domestic automotive suppliers and large foreign OEMs in the Czech Republic and Poland (Pavlínek \& Zenka, 2011; Gentile-Lüdecke \& Giroud, 2009, 2012) or in the case of FDI in the Polish dairy sector (Dries \& Swinnen, 2004).

\subsection{Heterogeneous local technological activities}

We find that foreign affiliates' technological capability, measured in terms of their innovation intensity (in comparison to competitors in the relevant market), has no significant effect on the extent of backward linkages (see Tables 5 and 6), but a significant positive effect on the intensity of backward linkages (see Tables 7 and 8). The result remains robust in all reported regressions. Thus, we cannot reject Hypothesis 
2, stating that the level of foreign affiliates' technological activities is positively associated with the intensity of backward linkages with domestic suppliers in the host economy.

Our evidence on a positive relationship between foreign subsidiaries' innovation intensity and backward linkage intensity add to existing evidence by Jindra et al. (2009) suggesting that foreign affiliates that consider themselves an important source of technological knowledge for their own R\&D and innovation have more intense backward linkages. On a more general level, our evidence is in line with the argument that technological heterogeneity of MNEs, and, importantly, their affiliates, matters in the diffusion of innovation to the host economy (Narula \& Dunning, 2010; Castellani \& Zanfei, 2006; Marin \& Bell, 2006; Driffield \& Love, 2007; Marin \& Sasidharan, 2010).

\subsection{Local autonomy over production and technology}

One of the main critiques of the recent literature on technological spillovers from FDI is that technology transfer depends not only on centralized decisions from the parent company, but also the decisions and strategies of subsidiaries themselves (Marin \& Bell, 2006). This raises the issue of strategic control of knowledge within MNEs (Castellani \& Zanfei, 2006). This is one of the first studies to assess quantitatively the effect of foreign affiliates' autonomy in decision-making over certain business functions on the backward linkage intensity.

Estimating Specifications 2a and 2b shows that foreign affiliates' autonomy over local production and operational management has no significant impact, whereas autonomy over basic and applied research increases the intensity of backward linkages (see Tables 7 and 8). These results are robust in all reported regressions. Therefore, we cannot reject Hypothesis 3a. This would support our proposition that foreign affiliates' autonomy over technologically-oriented business function increases backward linkage intensity. This argument could not be supported in earlier research on transition economies (Jindra et al., 2009).

In addition, we tested for the impact of responsibility transfer for new business functions from headquarters or other units to the foreign affiliate since entry of the foreign investor. We find a significant negative impact on the extent (see Tables 5 and 6) and no significant effect on intensity of backward 
linkages (see Table 7s and 8). These results are robust in all reported regressions. This does not support our Hypothesis 3b, assuming a positive relationship between competence transfer and intensity of backward linkages. Therefore, our evidence is not fully in line with case study evidence from Ireland showing that MNE plants with a high degree of strategic autonomy and a full range of higher-order functions are more likely to engage in knowledge transfer with local suppliers (Crone \& Roper, 2001).

\subsection{Embeddedness in the 'double network structure'}

Foreign affiliates' technological capabilities originate not only from their own competences, but from resources acquired inside the MNE network (Gupta \& Govindarajan, 2000), externally in the host economies (Almeida \& Phene, 2004; Yamin \& Otto, 2004; Belderbos et al., 2006), or both (Figueiredo, 2011). Therefore, we argue that this suggests not only a link between foreign affiliates' embeddedness in internal and external networks and its technological capabilities, but also the intensity of backward linkages.

We find that external technological embeddedness, measured as the importance attributed by the foreign affiliate to local suppliers/customers for own $R \& D$ and innovation, has a significant positive effect on the intensity of backward linkages (see Table 7 and 8). This result is robust in all reported regressions. We also find that internal technological embeddedness, measured as the importance attributed by the foreign affiliate to the MNE network as source for own R\&D or innovation, has a significant positive effect on the intensity of backward linkages. These results are robust in all reported regressions. Thus we cannot reject Hypotheses $4 \mathrm{a}$ and $4 \mathrm{~b}$, that the internal and external technological embeddedness of a foreign affiliate increase the intensity of backward linkages.

These results add to existing findings by Jindra et al. (2009) showing a positive relationship between internal technological embeddedness and intensity of backward linkages in transition countries, but find no significant relationship for foreign affiliates' external technological embeddedness. In addition, our findings support also the proposition of reciprocity in knowledge exchange between foreign affiliates and 
suppliers through activities such as $\mathrm{R} \& \mathrm{D}$ co-operation, joint product development or co-design, as suggested by Castellani \& Zanfei (2006).

\subsection{Other effects}

As for other firm-specific control effects, we find that foreign affiliates' local market orientation, measured in terms of the share of domestic in total sales, has a significant and positive effect on the extent of backward linkages (see Tables 5 and 6), in line with findings by Jordaan (2011) and Belderbos et al. (2001). However, we find that it has a significant negative effect on the intensity of backward linkages (see Tables 7 and 8), although this result is not robust in all reported regressions. The remaining estimation results show that, apart from market orientation, only the size of foreign affiliates has a significant impact. In fact, it decreases the probability of intense backward linkage effects. No other firmspecific control has a significant effect on the intensity of backward linkages. The same applies to the industry dummies that approximate the technological intensity of the respective industry group to which the foreign affiliates belong. We find significant country-specific effects.

\section{CONCLUDING REMARKS}

The contributions from our research to the literature on the subject are two-fold: First, we show evidence that the relationship between the extent of foreign affiliates' local sourcing and corresponding knowledge transfer to local suppliers does not follow a positive linear distribution, as generally assumed. Instead, our evidence suggests a non-linear relationship with decreasing returns, levelling off after a threshold of $20 \%$ local sourcing in total supplies of the foreign affiliate. This could imply that it is foreign affiliates' integration in global production networks, rather than their share of local content, that is associated with knowledge transfer to local suppliers in the host economy.

Second, our evidence substantiates the argument that heterogeneity of MNEs and their foreign affiliates matters for the diffusion of innovation in the host economy. We can confirm existing evidence that affiliates' technological capability increases the backward linkage intensity. In addition, we show robust evidence that foreign affiliates' autonomy over technology-related business functions, and their 
technological embeddedness with the MNE internal and external networks, is associated with knowledge transfer via backward linkages.

From a policy perspective, our results suggest that local content requirements for foreign investors may generate adverse effects with regard to knowledge transfer to domestic suppliers. The simple assumption that 'the more local inputs are bought locally, the better for the economy' does not hold. Of course, mere absence of local-content requirements does not automatically lead to spillovers and smooth industrial upgrading of domestic firms (Moran, 1998). Therefore, linkage promotion policy should target matching between foreign affiliates and local firms, and upgrading of local suppliers' capabilities. In order to facilitate knowledge transfer from foreign firms in transition and developing countries, it is paramount to stimulate technological activities in existing foreign affiliates, as well as technological co-operation between domestic firms and affiliates. Linkage promotion programs for foreign investors need to be complemented by other initiatives to build public and private technological capabilities and opportunities.

Rugraff (2008) holds that Central European countries have adopted, by and large, FDI policy models allowing MNEs to take advantage of various incentives offered, without sufficient incentives to encourage them to interact with the local environment; this lowers the probability for spillover effects. In this context, there is room for more FDI-specific policy measures with reduced emphasis on cost advantages, and more attention to the development of specialized location-specific assets, and/or on the creation of clusters around MNEs (Narula, 2010; Gentile-Lüdecke \& Giroud, 2009). Policy-makers are increasingly confronted with competitive bidding for FDI in general, and in particular, for FDI in R\&D between "high order' and 'intermediate' regions within and between countries (Cantwell \& Iammarino, 2003). Therefore, only a few regions in transition countries are going to be successful in this bidding process.

This paper also advances a novel approach to assess the developmental effects of FDI via backward linkages, complementary to the widely used production function approach to assess the effects of FDI on domestic firms' productivity. Despite this notable contribution, the suggested approach suffers from limitations: Firstly, the measure of backward linkage intensity relies upon a self-reported assessment by the foreign affiliate. We measure knowledge flow at the sending end (foreign affiliate) and not receiving end (domestic supplier). In addition, we are unable to draw any conclusion with regard to the economic effects of the corresponding knowledge flows for domestic suppliers. Secondly, 'domestic suppliers' are composed of foreign-owned suppliers and indigenous suppliers. The survey was unable to discriminate 
between these two categories. Our results might be biased, as existing studies suggest that the intensity of backward linkages is much higher in relationships established between foreign-owned firms (foreign affiliates buying from foreign-owned suppliers), as compared to relationships with indigenous suppliers (see for example Pavlínek \& Janak, 2007; Rugraff, 2010). Finally, some foreign affiliates may find it difficult to respond appropriately and accurately when they co-operate with a large number of different domestic suppliers.

There are several ways to improve the suggested approach: One way would be to take more explicitly into account the heterogeneity of backward linkages. Saliola \& Zanfei (2009) suggest differentiating linkages of foreign affiliates with regard to their knowledge intensity, collaborative content and their potential for upgrading for the respective partners. Here, we use information on the 'relative importance of affiliates' as a source of knowledge for R\&D and innovation by domestic suppliers' as a proxy for knowledge transfer. Alternative measures could be to ask foreign affiliates whether they share technological knowledge with domestic suppliers (free or in exchange) or whether foreign affiliates initiate product or process innovation conducted by domestic suppliers. Using surveys to suppliers, Gentile-Lüdecke \& Giroud $(2009,2012)$ and Jordaan (2011) differentiate types of technological support (product design, machinery, special tools, technical production, quality control, training) or knowledge acquired from foreign affiliates (product and process technology, organizational and managerial knowhow). It would be fruitful for future large-scale surveys to cover these dimensions systematically, in order to understand the impact of linkage heterogeneity on the technological spillover potential.

\section{NOTES}

${ }^{1}$ Halle Institute for Economic Research (IWH)

${ }^{2}$ The dummies reflect the OECD classification of High-tech, Medium-high-tech, Medium-low-tech, and Low-tech industries. We use the Medium-low-tech as control group because of the fact that technological content of trade relationships with domestic suppliers differs across different industries. Thus, technological intensity of the industry in which the foreign affiliate operates may be a bias in the estimation results for backward linkages' intensity.

${ }^{3}$ The first interval dummy takes the value of one, if the share of domestic supplies is below $20 \%$. The second is one for a share between $20-40 \%$, etc. In the regression, the first interval is taken as the base category. Compared to quintile dummies, this choice of intervals offers the advantage that the coefficients are comparable, since they correspond to uniform intervals. 


\section{REFERENCES}

Almeida, P., \& Phene, A. (2004). Subsidiaries and knowledge creation: The influence of the MNC and host country on innovation. Strategic Management Journal, 25, 847-864.

Andersson, U., \& Forsgren, M. (2000). In search of centers of excellence: network embeddedness and subsidiary roles in multinational corporations. Management International Review, 40(4): 329-50.

Belderbos, R., Capannelli, G., \& Fukao, K. (2001). Backward vertical linkages of foreign manufacturing affiliates: evidence from Japanese multinationals, World Development, 29(1), 189-208.

Belderbos, R., Carree, M., \& Lokshin, B (2006). Complementarity in R\&D Co-operation Strategies, Review of Industrial Organization, 28(4), 401-426.

Birkinshaw, J. M., Hood, N., \& Jonsson, S. (1998). Building firm-specific advantages in multinational corporations: The role of subsidiary initiative, Strategic Management Journal, 19(3), 221-242.

Cantwell, J. (1995). The globalization of technology: what remains of the product cycle model? Cambridge Journal of Economics, 19, 155-174.

Cantwell, J., \& Iguchi, C. (2005). Effects of backward linkages to local suppliers' development path: The case of the Malaysian electrical and electronics industry. In A. Giroud, A. T. Mohr, \& D. Yang (Eds.). Multinationals and Asia: Organizational and Institutional Relationships, 54-71. London, New York: Routledge.

Cantwell, J., \& Iammarino, S. (2003). Multinational Corporations and European Regional Systems of Innovation. London: Routledge.

Castellani, D., \& Zanfei, A. (2006). Multinational Firms, Innovation and Productivity. Cheltenham: Edward Elgar.

Chung, W. (2001). Identifying technology transfer in foreign direct investment: influence of industry conditions and investing motives, Journal of International Business Studies, 32, 211-229.

Cohen, W. M., \& Levinthal, D. A. (1990). Absorptive capacity: A new perspective on learning and innovation, Administrative Science Quarterly, 35, 128-152. 
Crespo, N., \& Fontoura, M.P. (2007). Determinant Factors of FDI Spillovers - What Do We Really Know?, World Development, 35(3): 410-425.

Crone, M., \& Roper, S. (2001). Local learning from multinational plants: Knowledge transfers in the supply chain, Regional Studies, 35(6), 535-548.

Damijan, J. P., Knell, M., Majcen, B., \& Rojec, M. (2003). The role of FDI, R\&D accumulation and trade in transferring technology to transition countries: Evidence from firm panel data for eight transition countries, Economic Systems, 27, 189-204.

Damijan, J. P., Rojec, M., Majcen, B., \& Knell, M. (2008). Impact of Firm Heterogeneity on Direct and Spillover Effects of FDI: Micro Evidence from 10 Transition Countries, LIOS Discussion Paper Series, 218/2008.

Dries, L., \& Swinnen, J. F. M. (2004). Foreign direct investment, vertical integration, and local suppliers: Evidence from the Polish dairy sector, World Development, 32(9), 1525-1544.

Driffield, N., \& Love, J. H. (2007). Linking FDI motivation and host economy productivity effects: conceptual and empirical analysis, Journal of International Business Studies, 38(3), 460-473.

Dunning, J.H., \& Lundan, S.M. (2008). Multinational Enterprises and the Global Economy. Cheltenham: Edward Elgar.

Eberhardt, M., McLaren, J., Millington, A., \& Wilkinson, B. (2004). Multiple sources of component localization in China, European Management Journal, 22(3), 290-303.

Figueiredo, P.N. (2011). The role of dual embeddedness in the innovative performance of MNE subsidiaries: Evidence from Brazil, Journal of Management Studies, 48(2), 417-440.

Findlay, R. (1978). Relative backwardness, direct foreign investment and the transfer of technology: A simple dynamic model, Quarterly Journal of Economics, 92(1), 1-16.

Forsgren, M., Holm, U., \& Johanson, J. (2006). Managing the embedded multinational: A business network view. Cheltenham: Edward Elgar.

Gerschenkron, A. (1962). Economic Backwardness in historical perspective, 3-29 in B.F. Hoselitz (ed.) The progress of underdeveloped areas, Chicago: University of Chicago Press. 
Gentile-Lüdecke, S., \& Giroud, A. (2009). Does the East Learn from the West? How Polish Automotive Suppliers Learn from Western MNEs, Journal of East-West Business, 15(3), 271-294.

Gentile-Lüdecke, S., \& Giroud, A. (2012). Knowledge Transfer from TNCs and Upgrading of Domestic Firms: The Polish Automotive Sector, World Development, 40(4), 798-807.

Giroud, A., and Scott-Kennel, J. (2009). MNE linkages in international business: a framework for analysis, International Business Review, 18, 555-566.

Günther, J. Jindra, B., \& Stephan, J. (2009). Does Local Technology matter for Foreign Investors in Central and Eastern Europe? - Evidence from the IWH FDI Micro Database, Journal of East West Business, 15(3-4), 210-247.

Günther, A. Gauselmann, P., Marek, J. Stephan, \& Jindra, B. (2011). An Introduction to the IWH FDI Micro database, Journal of Applied Social Science Studies, 131(3), 529-546.

Gupta, A. K., \& Govindarajan, V. (2000). Knowledge flows within multinational corporations, Strategic Management Journal, 21(4), 473-496.

Halpern, L., \& Muraközy, B. (2007). Does Distance matter in Spillover?, The Economics of Transition, The European Bank for Reconstruction and Development, 15, 781-805.

Hansen, M. W., Pedersen, T., \& Petersen, B. (2009). MNC strategies and linkage effects in developing countries, Journal of World Business, 44(2), 121-130.

Hirschman, A.O. (1958). The Strategy of Economic Development, New Haven: Yale University Press.

Hymer, S.H. (1960). International Operations of National Firms: A Study of Direct Foreign Investment. Doctoral dissertation (published 1976), Cambridge (MA): MIT Press.

Javorcik-Smarzynska, B. (2004). Does foreign direct investment increase the productivity of domestic firms? In search of spillovers through backward linkages, American Economic Review, 94(3), 605627.

Javorcik-Smarzynska, B., \& Spatareanu, M. (2011). Does it matter where you come from? Vertical spillovers from foreign direct investment and the origin of investors, Journal of Development Economics, 96(1), 126-138. 
Jindra, B., Giroud, A., \& Scott-Kennel, J. (2009). Subsidiary roles, vertical linkages and economic development: Lessons from transition economies, Journal of World Business, 44(2), 167-179.

Jindra, B. (2005). Theories and review of latest research on the effects of FDI in CEE, 3-76 in J. Stephan (Ed.). Technology Transfer via Foreign Direct Investment in Central and Eastern Europe: Theory Method of Research - Empirical Evidence. Basingstoke: Palgrave MacMillan.

Jordaan, J.A. (2011). FDI, local sourcing, and supportive linkages with domestic suppliers: The case of Monterey, Mexico, World Development, 39(4), 620-632.

Lall, S. (1980). Vertical Inter-Firm Linkages in LDCs: An empirical study, Oxford Bulletin of Economics and Statistics, 42(3), 203-226.

Lin, P., \& Saggi, K. (2007). Multinational firms, exclusivity, and backward linkages, Journal of International Economics, 71, 206-220.

Liu, B.J. (2010). MNEs and Local Linkages: Evidence from Taiwanese Affiliates, World Development, 39(4): 633-647.

Manea, J. \& Pearce, R. (2006). MNEs' Strategies in Central and Eastern Europe: key elements of subsidiary behavior, Management International Review, 46(2), 235-255.

Marin, A., \& Bell, M. (2006). Technology spillovers from foreign direct investment (FDI): The active role of MNC subsidiaries in Argentina in the 1990s, Journal of Development Studies, 42(4), 678-697.

Marin, A., \& Sasidharan, S. (2010). Heterogeneous MNC subsidiaries and technological spillovers: Explaining positive and negative effects in India, Research Policy, 39, 1227-1241.

Meyer, K.E., \& Sinani, E. (2009). When and where does FDI generate positive spillovers? A metaanalysis, Journal of International Business Studies, 40(7), 1075-1094.

Moran, T.H. (1998) Foreign direct investment and development: The new policy agenda for developing countries and economies in transition, Washington DC: Institute for International Economics.

Narula, R. (2010). Attracting and Embedding R\&D in Multinational Firms: Policy Options for EU New Member States, 150-176 in S. Radosevic \& A. Kaderabkova (Eds.). Challenges For European 
Innovation Policy: Cohesion and Excellence from a Schumpeterian Perspective. Cheltenham: Edward Elgar.

Narula, R., \& Dunning, J.H. (2010). Multinational enterprises, development and globalization: Some clarifications and a research agenda, Oxford Development Studies, 38(3), 263-287.

Pavlínek, P., \& Janak, L. (2007). Regional restructuring of the Skoda auto supplier network in the Czech Republic, European Urban and Regional Studies 14(2), 133-155.

Pavlínek, P., \& Ženka, J. (2011). Upgrading in the automotive industry: Firm-level evidence from Central Europe, Journal of Economic Geography, 11(3), 559-586.

Rodríguez-Clare, A. (1996). Multinationals, linkages and economic development, American Economic Review, 86(4), 852-873.

Rugraff, E. (2008). Are the FDI policies of the Central European countries efficient? Post-Communist Economies, 20(3), 303-316.

Rugraff E. (2010). FDI and supplier-oriented upgrading in the Czech motor vehicle industry, Regional Studies, 44(5), 627-638.

Saliola, F., \& Zanfei, A (2009). Multinational firms, global value chains and the organization of knowledge transfer, Research Policy, 38, 369-381.

Teece, D.J. (1976). The multinational corporation and the resource cost of international technology transfer, Cambridge, MA.: Ballinger.

UNCTAD (2001). World Investment Report 2001: Promoting Linkages. New York, Geneva: United Nations.

Veblen, T. (1915). Imperial Germany and the industrial revolution. London: Macmillan.

Wang, J.-Y., \& Blomström, M. (1992). Foreign investment and technology transfer: A simple model. European Economic Review, 36, 137-151.

Williamson, O.E. (1985). The Economic Institutions of Capitalism: Firms, Markets, Relational Contracting, New York: Free Press, London: Collier Macmillan. 
Yamin, M., \& Otto, J. (2004). Patterns of knowledge flows and MNE innovative performance, Journal of International Management, 10(2), 239-258.

Zanfei, A. (2000). Trans-national firms and the changing organization of innovative activities. Cambridge Journal of Economics, 24, 515-542.

Zanfei, A. (2012). Effects, Not Externalities, European Journal of Development Research, 24(1), 8-14. 


\section{TABLES}

Table A: Descriptive presentation of the final sample per country

\begin{tabular}{llll} 
Country & Response Rate $(\%$ in Nb of firms) & Nb. firms & in $\%$ \\
Croatia & 65.45 & 144 & 17.80 \\
Slovenia & 10.96 & 40 & 4.94 \\
Poland & 7.28 & 110 & 13.60 \\
Romania & 6.62 & 220 & 27.19 \\
East Germany & 20.37 & 222 & 27.44 \\
EG - WG MNEs & 22.67 & 73 & 9.02 \\
Total & 11.84 & 809 & \\
\hline
\end{tabular}

Source: IWH-FDI-Micro database, Methodological note (2007)

Table 1: Structure of supplies across the sample

\begin{tabular}{lllllll}
\hline Supplies from $(\mathrm{n}=772)$ & $\begin{array}{l}\text { Mean } \\
\text { (in \%) }\end{array}$ & $\begin{array}{l}\text { Standard } \\
\text { deviation }\end{array}$ & $\begin{array}{l}\text { Skewed- } \\
\text { ness }\end{array}$ & $\begin{array}{l}\text { Standard } \\
\text { error }\end{array}$ & Kurtosis & $\begin{array}{l}\text { Standard } \\
\text { error }\end{array}$ \\
Imports from foreign parent & 21.34 & 32.00 & 1.45 & 0.09 & 0.70 & 0.18 \\
Other imports & 24.45 & 24.45 & 1.19 & 0.09 & 0.32 & 0.18 \\
Domestic subsidiaries of foreign owner & 6.10 & 18.54 & 3.60 & 0.09 & 12.80 & 0.18 \\
Domestic suppliers & 48.24 & 35.32 & 0.04 & 0.09 & -1.42 & 0.18 \\
\hline
\end{tabular}

Source: IWH-FDI-Micro database (2007), authors' calculations.

Table 2: Extent and intensity of backward linkages across countries

\begin{tabular}{|c|c|c|c|c|c|c|}
\hline \multirow[t]{2}{*}{ Country (n=809) } & \multicolumn{3}{|c|}{ Extent } & \multicolumn{3}{|c|}{ Intensity } \\
\hline & $\begin{array}{l}\text { Mean } \\
\text { (in \%) }\end{array}$ & $\begin{array}{l}\text { Standard } \\
\text { deviation }\end{array}$ & $\begin{array}{l}\text { Difference } \\
\text { to sample }\end{array}$ & Mean & $\begin{array}{l}\text { Standard } \\
\text { deviation }\end{array}$ & $\begin{array}{l}\text { Difference } \\
\text { to sample }\end{array}$ \\
\hline Poland & 53.30 & 33.34 & 6.00 & 2.53 & 1.14 & $0.39 * *$ \\
\hline Romania & 38.49 & 37.08 & $-13.45 * * *$ & 2.45 & 1.43 & $0.34 * *$ \\
\hline Croatia & 43.13 & 30.83 & $-6.09 *$ & 2.20 & 1.31 & 0.00 \\
\hline Slovenia & 43.61 & 29.73 & -4.78 & 2.25 & 1.19 & 0.05 \\
\hline East Germany & 57.07 & 35.17 & $13.73 * * *$ & 1.84 & 1.02 & $-0.54 * * *$ \\
\hline \multicolumn{7}{|c|}{$\begin{array}{l}\text { Source: IWH-FDI-Micro database (2007), authors' calculations. } \\
\text { Note: *=significant at the } 0.10 \text { level; } * *=\text { significant at the } 0.05 \text { level; ***=significant at the } 0.01 \text { level }\end{array}$} \\
\hline Table 3: Exter & & У & & & & \\
\hline \multirow[t]{2}{*}{ Industries $(\mathrm{n}=809)$} & & Extent & & & Intensity & \\
\hline & $\begin{array}{l}\text { Mean } \\
(\text { in } \%)\end{array}$ & $\begin{array}{l}\text { Standard } \\
\text { deviation }\end{array}$ & $\begin{array}{l}\text { Difference } \\
\text { to sample }\end{array}$ & Mean & $\begin{array}{l}\text { Standard } \\
\text { deviation }\end{array}$ & $\begin{array}{l}\text { Difference } \\
\text { to sample }\end{array}$ \\
\hline High-Tech & 51.04 & 34.49 & 3.16 & 1.93 & 1.14 & $-0.29 *$ \\
\hline Medium-High-Tech & 47.69 & 32.26 & -0.60 & 2.23 & 1.18 & 0.04 \\
\hline Medium-Low-Tech & 55.76 & 34.40 & $10.49 * * *$ & 2.21 & 1.21 & 0.01 \\
\hline Low-Tech & 42.62 & 36.77 & $-9.42 * * *$ & 2.24 & 1.29 & 0.06 \\
\hline
\end{tabular}

Source: IWH-FDI-Micro database (2007), authors' calculations.

Note: *=significant at the 0.10 level; $* *=$ significant at the 0.05 level; $* * *=$ significant at the 0.01 level 
Table 4: Variable measurement

\begin{tabular}{|c|c|c|}
\hline Variable & Code & Measurement \\
\hline $\begin{array}{l}\text { Extent of backward } \\
\text { Linkages }\end{array}$ & BL & $\begin{array}{l}\text { Share of supplies sources form domestic suppliers outside the MNE } \\
\text { network in total supplies (in } \% \text { ) }\end{array}$ \\
\hline $\begin{array}{l}\text { Intensity of backward } \\
\text { linkages }\end{array}$ & BLI & $\begin{array}{l}\text { 'Please evaluate the importance of your own firm as a source of } \\
\text { technological knowledge for R\&D or innovation for domestic suppliers } \\
\text { today' Possible answers: (1) not important, (2) little important, (3) } \\
\text { important, (4) very important, and (5) extremely important. }\end{array}$ \\
\hline Technological capability & INNO & $\begin{array}{l}\text { 'Please indicate the innovation intensity in comparison to your competitors } \\
\text { in the relevant market' Possible answers: } 1=\text { very low, } 2=\text { below average, } \\
3=\text { average, } 4=\text { above average, } 5=\text { very high. Average of value for } \\
\text { product, process, organizational and marketing innovation. }\end{array}$ \\
\hline Autonomy in production & AUTprod & $\begin{array}{l}\text { 'Please indicate to which degree production and operational management is } \\
\text { currently undertaken either by your firm or the foreign owner network } \\
\text { (HQ/other unit)'. Possible answers: } 1=\text { only your firm, } 2=\text { mainly your } \\
\text { firm, } 3 \text { = mainly foreign investor network, } 4=\text { only foreign network } \\
\text { (coding reversed for estimation). }\end{array}$ \\
\hline Autonomy in R\&D & AUTrd & $\begin{array}{l}\text { 'Please indicate to which degree basic and applied research is currently } \\
\text { undertaken either by your firm or the foreign owner network (HQ/other } \\
\text { unit)'. Possible answers: } 1=\text { only your firm, } 2=\text { mainly your firm, } 3= \\
\text { mainly foreign investor network, } 4=\text { only foreign network (coding } \\
\text { reversed for estimation). }\end{array}$ \\
\hline $\begin{array}{l}\text { External technological } \\
\text { embeddedness }\end{array}$ & TEext & $\begin{array}{l}\text { 'Please evaluate the importance of the R\&D carried out in collaboration } \\
\text { with local suppliers/ local customers for R\&D or innovation in your firm } \\
\text { today' Possible answers: } 1=\text { not important; } 2=\text { little important; } 3= \\
\text { important; } 4=\text { very important; } 5=\text { extremely important }\end{array}$ \\
\hline $\begin{array}{l}\text { Internal technological } \\
\text { embeddedness }\end{array}$ & TEint & $\begin{array}{l}\text { 'Please evaluate the importance of the R\&D carried out at the } \\
\text { headquarters/other unit of your foreign investor network knowledge for } \\
\text { R\&D or innovation in your firm today' Possible answers: } 1=\text { not } \\
\text { important; } 2=\text { little important; } 3=\text { important; } 4=\text { very important; } 5= \\
\text { extremely important }\end{array}$ \\
\hline $\begin{array}{l}\text { Transfer of autonomy in } \\
\text { business functions }\end{array}$ & AUTtransfer & $\begin{array}{l}\text { 'Please indicate the extent of responsibilities transfer with regard to new } \\
\text { business functions from headquarters and/or other units to your firm since } \\
\text { entry of the foreign investor.' Possible answers: } 1=\text { no transfer, } 2=\text { limited } \\
\text { transfer, } 3=\text { considerable transfer, } 4=\text { full transfer. }\end{array}$ \\
\hline Market orientation & LS & $\begin{array}{l}\text { Share of sales to domestic customers outside the MNE network in total } \\
\text { sales (in \%) }\end{array}$ \\
\hline Time since entry & AGE & Years since entry of foreign investor. \\
\hline Mode of entry & EM & $\begin{array}{l}\text { Dummy that equals one if the foreign investors entered the market through } \\
\text { a Greenfield investment, and zero otherwise. }\end{array}$ \\
\hline Affiliate size & Size & Number of employees of the foreign affiliate in 2005. \\
\hline Industry dummy & INDdum & $\begin{array}{l}\text { OECD classification of High-tech, Medium-high-tech, Medium-low-tech, } \\
\text { and Low-tech industries using Medium-low-tech as control group. }\end{array}$ \\
\hline Country dummy & Cdum & Host country dummy, using Romania as control group. \\
\hline
\end{tabular}


Table 5: Estimation results: Extent of backward linkages - OLS

Firm-specific effects

Technological capability

1.281
$(1.227)$
$4.201 * *$
$(1.978)$
$3.235 * *$
$(1.522)$
$-5.171 * * *$
$(1.607)$
$4.318 * * *$
$(1.480)$
-0.873
$(1.474)$

Autonomy in production management

Autonomy in basic and applied research

Responsibility transfer for new business function

(1.555)

$-4.792 * * *$

(1.609)

External technological embeddedness

$4.318^{*}$

$3.212 * *$

(1.456)

Internal technological embeddedness

$-0.916$

(1.408)

Firm-specific controls

Market orientation

$\begin{array}{lll} & 0.251 * * * & 0.223 * * * \\ & (0.0438) & (0.0434) \\ & 0.0255 & 0.0650 \\ & (0.348) & (0.345) \\ & -5.993 * * & -3.198 \\ & (2.976) & (3.016) \\ & -0.00333 & -0.00272 \\ & (0.00237) & (0.00257) \\ & & \\ 1.989 & 2.071 & 1.785 \\ (5.533) & (5.690) & (5.657) \\ 10.05 * & 7.017 & 7.538 \\ (5.773) & (5.908) & (5.937) \\ 2.743 & 0.840 & 0.784 \\ (5.715) & (5.886) & (5.885) \\ & & \\ 13.87 * * * & 8.294 * & 8.240 * \\ (4.512) & (4.522) & (4.551) \\ 5.626 & 3.201 & 1.751 \\ (5.060) & (4.853) & (5.180) \\ 19.04 * * * & 15.26 * * * & 13.86 * * * \\ (4.022) & (4.155) & (4.279) \\ 3.336 & 2.261 & 1.818 \\ (5.617) & (6.985) & (6.085)\end{array}$

Summary statistics

Number of observations

Prob $>F$

520

520

520

R-squared

0.000

0.000

0.000

0.144

0.153

0.199

Root MSE

32.98

32.74

32.02

Source: IWH-FDI-Micro database (2007), authors' calculations.

Note: $*=$ significant at the 0.10 level; $* *=$ significant at the 0.05 level; $* * *=$ significant at the 0.01 level 
Table 6: Estimation results: Extent of backward linkages - Tobit

Firm-specific effects

Technological capability

1.697

(1.632)

Autonomy in production management

Autonomy in basic and applied research

Responsibility transfer for new business function

External technological embeddedness

Internal technological embeddedness

Firm-specific controls

Market orientation

Time since entry

Greenfield market entry mode

Affiliate size

Industry dummies

MedHighTech

MedLowTech

LowTech

Country dummies

Poland

Croatia

East Germany

Slovenia

Summary statistics

Number of observations

Prob $>F$

Pseudo R2

Log pseudo 11

$-2134$
$7.247 * *$

(2.884)

$3.795^{*}$

(2.031)

$-6.226 * * *$

(2.108)

$5.817 * * *$

(1.899)

$-1.620$

(2.019)

$\begin{array}{lll} & 0.329 * * * & 0.292 * * * \\ & (0.0582) & (0.0570) \\ & 0.126 & 0.200 \\ & (0.458) & (0.451) \\ & -8.344 * * & -4.626 \\ & (3.924) & (3.966) \\ & -0.00428 & -0.00350 \\ & (0.00355) & (0.00370) \\ & & \\ 1.362 & 1.230 & 1.131 \\ (6.866) & (6.994) & (6.959) \\ 12.18 * & 8.168 & 8.888 \\ (7.203) & (7.344) & (7.337) \\ 2.469 & 0.0152 & -0.0688 \\ (7.130) & (7.297) & (7.269) \\ & & \\ 18.44 * * * & 11.07 * & 11.08 * \\ (5.833) & (5.872) & (5.861) \\ 8.299 & 5.049 & 3.067 \\ (6.353) & (6.049) & (6.473) \\ 24.80 * * * & 20.05 * * * & 17.96 * * * \\ (5.336) & (5.566) & (5.697) \\ 9.118 & 7.633 & 6.934 \\ (6.213) & (7.762) & (6.757) \\ & & \end{array}$

$7.515 * * *$

(2.865)

1.979

(2.064)

$-5.747 * * *$

(2.093)

$4.396^{* *}$

(1.843)

$-1.820$

(1.932)
1.613

$(1.555)$

Source: IWH-FDI-Micro database (2007), authors' calculations.

$\begin{array}{lll}520 & 520 & 520\end{array}$

$\begin{array}{lll}0.000 & 0.000 & 0.000\end{array}$

$\begin{array}{lll}0.019 & 0.020 & 0.027\end{array}$

0.027 $-2117$

Note: *=significant at the 0.10 level; **=significant at the 0.05 level; ***=significant at the 0.01 level 
Table 7: Estimation results: Backward Linkage Intensity - Ordered Probit

\begin{tabular}{|c|c|c|c|}
\hline Specifications & (2a) & $(2 a)$ & (2a) \\
\hline Extent of backward linkages & $\begin{array}{c}0.0330 * * * \\
(0.00559)\end{array}$ & $\begin{array}{l}0.0291 * * * \\
(0.00580)\end{array}$ & $\begin{array}{l}0.0282 * * * \\
(0.00591)\end{array}$ \\
\hline Squared sum of the extent of backward linkages & $\begin{array}{l}-0.000254 * * * \\
(5.28 \mathrm{e}-05)\end{array}$ & $\begin{array}{l}-0.000222 * * * \\
(5.53 \mathrm{e}-05)\end{array}$ & $\begin{array}{l}-0.000208 \text { *** } \\
(5.64 \mathrm{e}-05)\end{array}$ \\
\hline \multicolumn{4}{|l|}{ Firm-specific effects } \\
\hline Technological capability & & $\begin{array}{l}0.0776^{*} \\
(0.0446)\end{array}$ & $\begin{array}{l}0.0857^{*} \\
(0.0451)\end{array}$ \\
\hline Autonomy in production management & & $\begin{array}{l}0.0172 \\
(0.0753)\end{array}$ & $\begin{array}{l}0.0232 \\
(0.0751)\end{array}$ \\
\hline Autonomy in basic and applied research & & $\begin{array}{l}0.198 * * * \\
(0.0569)\end{array}$ & $\begin{array}{l}0.178 * * * \\
(0.0600)\end{array}$ \\
\hline Responsibility transfer for new business function & & $\begin{array}{l}0.0419 \\
(0.0559)\end{array}$ & $\begin{array}{l}0.0540 \\
(0.0564)\end{array}$ \\
\hline External technological embeddedness & & $\begin{array}{l}0.323 * * * \\
(0.0558)\end{array}$ & $\begin{array}{l}0.333 * * * \\
(0.0569)\end{array}$ \\
\hline Internal technological embeddedness & & $\begin{array}{l}0.348 * * * \\
(0.0589)\end{array}$ & $\begin{array}{l}0.341 * * * \\
(0.0588)\end{array}$ \\
\hline \multicolumn{4}{|l|}{ Firm-specific controls } \\
\hline Market orientation & & & $\begin{array}{l}-0.00293 * \\
(0.00158)\end{array}$ \\
\hline Time since entry & & & $\begin{array}{l}0.00220 \\
(0.0111)\end{array}$ \\
\hline Greenfield market entry mode & & & $\begin{array}{l}-0.155 \\
(0.103)\end{array}$ \\
\hline Affiliate size & & & $\begin{array}{l}-0.000256^{* * *} \\
(0.000103)\end{array}$ \\
\hline \multicolumn{4}{|l|}{ Industry dummies } \\
\hline MedHighTech & $\begin{array}{l}0.159 \\
(0.194)\end{array}$ & $\begin{array}{l}-0.00322 \\
(0.210)\end{array}$ & $\begin{array}{l}0.0476 \\
(0.205)\end{array}$ \\
\hline MedLowTech & $\begin{array}{l}0.112 \\
(0.197)\end{array}$ & $\begin{array}{l}0.0825 \\
(0.216)\end{array}$ & $\begin{array}{l}0.116 \\
(0.213)\end{array}$ \\
\hline LowTech & $\begin{array}{l}0.114 \\
(0.199)\end{array}$ & $\begin{array}{l}0.134 \\
(0.214)\end{array}$ & $\begin{array}{l}0.136 \\
(0.211)\end{array}$ \\
\hline \multicolumn{4}{|l|}{ Country dummies } \\
\hline Poland & $\begin{array}{l}-0.152 \\
(0.138)\end{array}$ & $\begin{array}{l}-0.474 * * * \\
(0.152)\end{array}$ & $\begin{array}{l}-0.480 * * * \\
(0.153)\end{array}$ \\
\hline Croatia & $\begin{array}{l}-0.425^{* *} \\
(0.193)\end{array}$ & $\begin{array}{l}-0.655^{* * * *} \\
(0.201)\end{array}$ & $\begin{array}{l}-0.729 * * * \\
(0.202)\end{array}$ \\
\hline East Germany & $\begin{array}{l}-0.739 * * * \\
(0.126)\end{array}$ & $\begin{array}{l}-0.776^{* * * *} \\
(0.138)\end{array}$ & $\begin{array}{l}-0.883 * * * \\
(0.149)\end{array}$ \\
\hline Slovenia & $\begin{array}{l}-0.221 \\
(0.227)\end{array}$ & $\begin{array}{l}-0.246 \\
(0.224)\end{array}$ & $\begin{array}{l}-0.338 \\
(0.229)\end{array}$ \\
\hline \multicolumn{4}{|l|}{ Summary statistics } \\
\hline Number of observations & 520 & 520 & 520 \\
\hline Wald Chi2 & 81.62 & 204.19 & 209.52 \\
\hline Prob Chi2 & 0.0000 & 0.0000 & 0.0000 \\
\hline Log Pseudo 11 & -718.6 & -642.0 & -636.7 \\
\hline
\end{tabular}

Source: IWH-FDI-Micro database (2007), authors' calculations.

Note: $*=$ significant at the 0.10 level; $* *=$ significant at the 0.05 level; $* * *=$ significant at the 0.01 level 


\section{Table 8: Estimation results: Backward Linkage Intensity - Ordered Probit}

\begin{tabular}{|c|c|c|c|}
\hline Specifications $(2 b)$ & Unrestricted & $\begin{array}{l}\text { Restricted of } \\
\text { linearity }\end{array}$ & $\begin{array}{l}\text { Restriction of } \\
\text { threshold }\end{array}$ \\
\hline \multirow[t]{2}{*}{ Dummy for extent of backward linkages of $20-40 \%$} & $0.778 * * *$ & $0.1205 * * *$ & $0.6531 * * *$ \\
\hline & $(0.158)$ & $(0.0296)$ & $(0.1184)$ \\
\hline \multirow[t]{2}{*}{ Dummy for extent of backward linkages of $40-60 \%$} & $0.750 * * *$ & $0.2410 * * *$ & $0.6531 * * *$ \\
\hline & $(0.174)$ & $(0.0592)$ & $(0.1184)$ \\
\hline \multirow[t]{2}{*}{ Dummy for extent of backward linkages of $60-80 \%$} & $0.595 * * *$ & $0.3614 * * *$ & $0.6531 * * *$ \\
\hline & $(0.142)$ & $(0.0888)$ & $(0.1184)$ \\
\hline \multirow[t]{2}{*}{ Dummy for extent of backward linkages of $80-100 \%$} & $0.633 * * *$ & $0.4819 * * *$ & $0.6531 * * *$ \\
\hline & $(0.150)$ & $(0.1184)$ & $(0.1184)$ \\
\hline \multicolumn{4}{|l|}{ Firm-specific effects } \\
\hline \multirow[t]{2}{*}{ Technological capability } & $0.0907 * *$ & $0.0943 * *$ & $0.0897 * *$ \\
\hline & $(0.0441)$ & $(0.0443)$ & $(0.0442)$ \\
\hline \multirow[t]{2}{*}{ Autonomy in production management } & 0.0191 & 0.0503 & 0.0237 \\
\hline & $(0.0754)$ & $(0.0738)$ & $(0.0747)$ \\
\hline \multirow[t]{2}{*}{ Autonomy in basic and applied research } & $0.177 * * *$ & $0.175^{* * *}$ & $0.1753 * * *$ \\
\hline & $(0.0611)$ & $(0.0601)$ & $(0.0609)$ \\
\hline \multirow{2}{*}{ Responsibility transfer for new business function } & 0.0409 & 0.0410 & 0.0456 \\
\hline & $(0.0559)$ & $(0.0550)$ & $(0.0554)$ \\
\hline \multirow[t]{2}{*}{ External technological embeddedness } & $0.344 * * *$ & $0.343 * * *$ & $0.3431 * * *$ \\
\hline & $(0.0580)$ & $(0.0557)$ & $(0.0571)$ \\
\hline \multirow[t]{2}{*}{ Internal technological embeddedness } & $0.327 * * *$ & $0.330 * * *$ & $0.3267 * * *$ \\
\hline & $(0.0585)$ & $(0.0585)$ & $(0.0585)$ \\
\hline \multicolumn{4}{|l|}{ Firm-specific controls } \\
\hline \multirow[t]{2}{*}{ Market orientation } & -0.00239 & $-0.0029 *$ & $-0.0027 *$ \\
\hline & $(0.00159)$ & $(0.0015)$ & $(0.0015)$ \\
\hline \multirow[t]{2}{*}{ Time since entry } & -0.00322 & -0.0049 & -0.0015 \\
\hline & $(0.0112)$ & $(0.0110)$ & $(0.0111)$ \\
\hline \multirow[t]{2}{*}{ Greenfield market entry mode } & -0.148 & $-0.203 * *$ & $-0.1540 * * *$ \\
\hline & $(0.104)$ & $(0.102)$ & $(0.1027)$ \\
\hline \multirow[t]{2}{*}{ Affiliate size } & $-0.000269 * *$ & $-0.00025^{* *}$ & $-0.00026 * *$ \\
\hline & $(0.000107)$ & $(0.0001)$ & $(0.0001)$ \\
\hline \multicolumn{4}{|l|}{ Industry dummies } \\
\hline \multirow{2}{*}{ MedHighTech } & 0.0755 & 0.0581 & 0.0669 \\
\hline & $(0.205)$ & $(0.204)$ & $(0.204)$ \\
\hline \multirow[t]{2}{*}{ MedLowTech } & 0.130 & 0.106 & 0.1194 \\
\hline & $(0.213)$ & $(0.210)$ & $(0.2116)$ \\
\hline \multirow[t]{2}{*}{ LowTech } & 0.164 & 0.095 & 0.1461 \\
\hline & $(0.211)$ & $(0.209)$ & $(0.209)$ \\
\hline \multicolumn{4}{|l|}{ Country dummies } \\
\hline Poland & $-0.411 * * *$ & $-0.403 * * *$ & $-0.4272 * * *$ \\
\hline & $(0.153)$ & $(0.149)$ & $(0.150)$ \\
\hline Croatia & $-0.648 * * *$ & $-0.600 * * *$ & $-0.6459 * * *$ \\
\hline & $(0.200)$ & $(0.194)$ & $(0.1992)$ \\
\hline East Germany & $-0.842 * * *$ & $-0.819 * * *$ & $-0.8574 * * *$ \\
\hline & $(0.146)$ & $(0.147)$ & $(0.1460)$ \\
\hline Slovenia & -0.287 & -0.234 & -0.2813 \\
\hline & $(0.233)$ & $(0.224)$ & $(0.2305)$ \\
\hline Summary statistics & & & \\
\hline Number of observations & 520 & 520 & 520 \\
\hline Wald Chi2 & 208.36 & 197.50 & 209.12 \\
\hline Prob Chi2 & 0.0000 & 0.0000 & 0.0000 \\
\hline Log Pseudo 11 & -635.4 & -645.9 & -636.3 \\
\hline
\end{tabular}

Source: IWH-FDI-Micro database (2007), authors' calculations.

Note: *=significant at the 0.10 level; $* *=$ significant at the 0.05 level; $* * *=$ significant at the 0.01 level

\footnotetext{
${ }^{1}$ Halle Institute for Economic Research (IWH)
} 


\footnotetext{
${ }^{2}$ The dummies reflect the OECD classification of High-tech, Medium-high-tech, Medium-low-tech, and Low-tech industries. We use the Medium-low-tech as control group because of the fact that technological content of trade relationships with domestic suppliers differs across different industries. Thus, technological intensity of the industry in which the foreign affiliate operates may be a bias in the estimation results for backward linkages' intensity.

${ }^{3}$ The first interval dummy takes the value of one, if the share of domestic supplies is below $20 \%$. The second is one for a share between $20-40 \%$, etc. In the regression, the first interval is taken as the base category. Compared to quintile dummies, this choice of intervals offers the advantage that the coefficients are comparable, since they correspond to uniform intervals.
} 